\title{
Does sophistication increase partisan bias? Evidence from a cross-
}

\section{national analysis}

This article has been accepted for publication in European Politics and Society, published by Taylor \& Francis: Patkós, V., \& Szántó, A. (2021). Does sophistication increase partisan bias? Evidence from a cross-national analysis. European Politics and Society, 22(3), 359-373.

https://doi.org/10.1080/23745118.2020.1769941

\begin{abstract}
Recently, considerable theoretical literature has emerged on voters' sophistication and its effect on democratic functioning. Some works argue that the political choices of more sophisticated voters lead to more favourable social outcomes (Brennan, 2017; Somin, 2016). However, Achen and Bartels (2016) argue that sophisticated citizens are at least as biased as the unsophisticated. This paper aims to clarify this link by investigating the role of education, information acquisition, and interest on bias. The question is tested on European Social Survey data. The results show that the level of bias is independent of education but is significantly related to both interest and newspaper reading. The findings fully support the interpretation of Achen and Bartels (2016) on the effect of sophistication.
\end{abstract}

Keywords: partisan bias; voting behaviour, political sophistication; European Social Survey 
Partisan bias generates systematic errors in citizens' political evaluations which contributes to suboptimal political outcomes. Some scholars argue that partisan bias primarily characterizes sophisticates rather than the politically unsophisticated, while others depict sophistication as a feature which could decrease bias. The links between sophistication and bias, therefore, are far from being clear.

Investigating the role of sophistication is particularly important, as in the last few years, a number of remarkable books have warned about the deleterious effect of voters' unsophistication, irrationality and ignorance on the quality of democratic functioning (Achen \& Bartels, 2016; Brennan, 2017; Caplan, 2011; Somin, 2016). These theories offer ground for the idea that constraining the suffrage of illiterate or unknowledgeable people could lead to better democratic outcomes (Brennan, 2009, 2017; Somin, 2016). These ideas become especially widespread in instances when the popular will deviates from the will of highly educated people, like in the case of the Brexit referendum and the victory of Donald Trump.

The puzzling question emerges from the contradiction between theories highlighting the significance of sophistication in improving democratic functioning and theories built on empirical evidence according to which sophisticated voters are more biased information processors (Abramowitz \& Saunders, 2008; Achen \& Bartels, 2016; Campbell, Converse, Miller, \& Stokes, 1960; Lodge \& Hamill, 1986; Lodge \& Taber, 2005; Tilley \& Hobolt, 2011; Wagner \& Tarlov \& Vivyan, 2014; (while for exceptions see Anduiza, Gallego, \& Muñoz, 2013; Flynn, 2016; Kahne \& Bowyer, 2017; Taber, Cann, \& Kucsova, 2009). To sum up, while the question is a fundamental one, both theoretical expectations and empirical results are mixed. These contradictions might easily lead to counterintuitive scientific claims and commonplace generalisations.

This paper contributes to this important debate by investigating the links between sophistication and bias on a large repeated cross-national sample of European voters. We test 
our question with multivariate regression models on the repeated cross-sectional dataset of the European Social Survey project. The dataset includes individual data from 30 European countries and seven survey rounds between 2001 and 2015 .

The results show that political interest and awareness strongly enhance bias, but the effect of education is insignificant. The results of our study do not provide support for the idea that 'epistocracies' could potentially outperform democracies (Brennan, 2017), but neither they fully support the concerns of those who argue that sophistication exacerbates bias - the educated seem just as biased information processors as the uneducated. These results highlight that the relationship between political sophistication and partisan bias is far more complex than either the pessimistic or the optimistic scenarios described and they question fundamental claims of the existent literature in connection with the role of education.

\section{Evidence on the link between sophistication and bias}

On Robert C. Luskin's account (1990), political sophisticates are those who have the necessary motivation to seek and process political information, the ability to handle information, and who make an effort to do so (see also Converse, 2006). High cognitive capacities and substantial effort to acquire information are expected to enable citizens to make sound judgements and to articulate their opinions without too much reliance on party heuristics (Dalton, 1984, 2007). This leads to the theoretical assumption that more political information and higher interest are conducive to more grounded, more rational and less biased decisions in comparison with the decisions of citizens with fewer of these capacities.

In contrast with these expectations, empirical research predominantly finds a positive connection between citizens' sophistication and partisan attitudes. The results of Abramowitz and Saunders (2008) on the American electorate demonstrates that interest, awareness and 
partisanship are strongly interrelated, as Converse and his co-authors (1960) demonstrated half a century ago. They found that neutral or centrist political attitudes are still strongly correlated with the state of being uninformed and disinterest, while the most interested and politically aware are strongly polarised in an ideological sense. A bunch of interesting works reinforce this perplexing image of partisanship by investigating the gap between more and less sophisticated Democrats and Republicans on a set of questions with high partisan relevance. With growing levels of education and interest, the members of these two partisan groups showed growing level of dissent on the existence of evolution, anthropogenic global warming and questions related to the Iraqi war (Joslyn \& Haider-Markel, 2014; Tesler, 2018). In a similar vein, Taber and Lodge (2006) and Shani (2006) showed that those having more factual knowledge about non-partisan aspects of politics had a stronger tendency to adopt party labels when recalling facts with partisan relevance compared to those with little factual knowledge. Reviewing a set of similar results, Achen and Bartels (2016, p. 294) argue that 'political rationalization is often most powerful among people who are well-informed and politically engaged, since their fundamental political commitments tend to be the most consistent and strongly held'. They also argue that sophistication does not provide a remedy for partisan bias, but on the contrary, it may enhance partisan motives. As they conclude, the politically interested are less likely to pay attention to the recent political situation, as their political attitudes are more stable than their less interested counterparts'. Druckman and Lupia arrive at similar conclusions on the nature of voters" thinking, formulating that "the most aware individuals" beliefs are less likely to be changed by new information as they have "the ability to generate internal counter-arguments" and their knowledge "limits the extent to which new information surprises them" (Druckman \& Lupia, 2000, p. 14) (see also Taber \& Lodge, 2006; Zaller, 1992).

Furthermore, Lodge and Taber (2005) show that the positive relationship between interest, information and bias does not only have cognitive motives, but also affective ones, as 
sophisticates are more strongly influenced by their affective responses when facing political concepts. As they conclude, while bias is generally present in political evaluations, political sophisticates with strong political attitudes are the most biased information processors ${ }^{\mathrm{i}}$.

In contrast to these results, there is only limited empirical evidence (primarily experimental) which supports the idea that sophistication might be positively related to more objective evaluations. Anduiza et al. (2013) show that politically informed people apply less bias when evaluating corruption cases. The results of Taber et al. (2009) are similar, yet inconclusive. Eveland and Scheufele (2000) show that if citizens are exposed to a new piece of political information, the original knowledge gap becomes more substantial among less educated citizens and more educated ones, which suggests that sophistication is beneficial for the processing of additional elements of knowledge. According to Kahne and Bowyer (2017), the level of political knowledge is unrelated to the extent of bias applied.

On the whole, there is a remarkable amount of empirical evidence - primarily based on samples of American citizens - on the positive link between political sophistication and biased views, and less empirical support for an opposite or no effect. We see two important characteristics of the literature that may account for mixed results. First, the overwhelming majority of empirical evidence is produced in the US which offers a special, stable bipartisan context for voters, hence the evidence coming from this context may not be generalizable to other polities. Second, a notable part of works addressing this question either investigates one particular aspect of sophistication (e.g., interest or education) or merges several aspects into one. We argue that such ambiguous operationalisations easily produce spurious correlations between partisan bias and sophistication as they might confound the role of well-distinguishable aspects of sophistication, such as education, political interest, and acquisition of political information. Therefore, we designed our research to overcome these ambiguities. We investigate the question on data from 30 European countries, mostly multi-party polities. The 
data sets we use are from the European Social Survey project, which produces one of the bestquality individual level, cross-national datasets. Methodologically, instead of merging different aspects of political sophistication into one composite index, we test the effect of the three most often investigated elements (political interest, education and political news consumption) separately. This approach enables us to understand the role of sophistication from a nuanced perspective.

\section{Conceptualizing and measuring bias}

People's beliefs and evaluations rely to a large extent on what Lippmann (1922, p. 4) calls the "pseudo environment" which is "a representation of the environment which is in lesser or greater degree made by man himself” (Lippmann, 1922, p. 4). We refer to the distance between the real political environment and the pseudo-environment in one's mind as absolute bias. In other words, evaluations relying on pseudo environments which are more distant from the real environment are more biased.

While "bias" generally implies that there is a gap between one's beliefs and reality, when speaking about political evaluations, this is not always the case. When asking people about their evaluation or opinion about any aspect of politics we often cannot set up a benchmark to differentiate between right or wrong answers. Therefore, when measuring bias in non-factual beliefs, the most frequently applied technique is to measure the relative bias which is the deviation of the evaluation of a partisan group from the evaluation of the opposing partisan group. Nonetheless, the driving forces behind absolute and relative bias are the same. The opinions of Democrats and Republicans in factual questions (like economic performance or crime rate) deviate from each other in a similar manner as in the case of non-factual questions (like the perceived position of the US in the world or perceived moral climate) (Shani, 2006). Therefore, it is possible to make inferences about the amount of partisan bias based on the gap between non-factual evaluations of partisan groups. 
Measuring partisan bias in survey context is a challenging task (Flynn, Nyhan, \& Reifler, 2017), and this is especially true in a European multi-party context. In order to estimate partisan bias, first, we must identify well-distinguishable groups along party lines, and then, we have to choose a topic on which the views of these partisan groups differ due to their dissimilar partisan interests. In an American context, the two relevant political groups are Democrats and Republicans, while the topic of partisan relevance generally is a cabinet-related performance question, as for example, how respondents evaluate the performance of the president, the performance of the economy or some specific policy measures (Bartels, 2002; Bisgaard, 2015; Jerit \& Barabas, 2012; Shani, 2006). To stay as close to the American research tradition as possible, and at the same time to acknowledge the differences between the political characteristics of European polities and the US, we propose to compare the satisfaction of government and opposition voters about the performance of their national government. ${ }^{\mathrm{ii}}$ While these satisfaction scores may contain evaluations about single policy decisions, the evaluation of the government is strongly related to previously established beliefs and partisan preferences. Government supporters are supposed to have positively biased evaluations, while the supporters of opposition parties are likely to have negatively biased evaluations on how the government performs.

Comparing the political evaluations of voters based on their government/opposition status is not a novelty, there is a growing body of literature that approaches the so called "winner-loser gap" on questions of political satisfaction and trust (Anderson \& LoTempio, 2002; Anderson \& Tverdova, 2001; Blais \& Gélineau, 2007; Brunell \& Buchler, 2012; Craig, Martinez, Gainous, \& Kane, 2006; Curini, Jou, \& Memoli, 2012; Howell \& Justwan, 2013; Singh, Karakoç, \& Blais, 2012; Singh, Lago, \& Blais, 2011). Nevertheless, the “winner-loser gap” has not been explicitly linked to partisan bias in the European literature. We argue that satisfaction with the performance of the national government is an adequate question to measure bias in 
comparative European survey research, as it is a general, extensively surveyed and easily interpretable item with clear partisan relevance for government and opposition party groups.

\section{Data and variables}

The analysis of the study relies on the pooled dataset of the first seven rounds of the European Social Survey project (European Social Survey, 2015). To limit the heterogeneity of the sample in terms of cultural and socio-political background, we analysed the electorates of 30 European democracies, including the 28 member states of the European Union and Norway and Switzerland. The pooled dataset contains more than 230000 individual subjects and 138 country-cases (see Appendix 1). However, the statistical models rely on a significantly reduced number of observations compared to the original database, primarily due to the high rate of subjects who did not participate in the previous elections or refused to answer which party they voted for.

It is important to note that the sample used for answering the research question includes only those voters who both participated in the last national elections and were willing to report their vote choice or who felt close to a party. This implicates that our conclusions apply to those who show at least some minimal interest in politics.

\section{Dependent and independent variables}


Based on what has been mentioned above, the dependent variable of the research is satisfaction with the national government ${ }^{i i i}$, measured on a 0 to 10 scale, ranging from "extremely dissatisfied" to "extremely satisfied".

One key independent variable of the research is being a government or an opposition party voter. Data about government composition and dates of elections and investitures are retrieved from the dataset of the Comparative Political Data Set project (Armingeon, Isler, Knöpfel, \& Weisstanner, 2016). We coded those respondents "government voters" who indicated to have voted for a party which was in office during the fieldwork period of the survey. In order to make a clear distinction between government and opposition parties, we excluded the cases when fieldwork period overlapped with the period between parliamentary elections and the investiture of the new government, the cases when the incumbent government was a technocratic one, and finally, we excluded the supporters of two small parties that left their government coalition during the fieldwork period.

Other independent variables are the main aspects of political sophistication. As political sophistication has at least three widely analysed yet empirically different facets, we investigated all of them, namely, political information acquisition, level of education and political interest.

Education is measured by the number of years spent in the education system, assuming values between 0 and 35 (we excluded the few cases when the time spent in education exceeded 35 years).

Political interest is measured on a four-point scale which ranges from (1), not at all to (4), very interested.

We measure acquisition of political information with the time spent on gaining political information on an average weekday. The dataset contains information on three political news sources, newspaper, radio, and television. Answers range from 0 (not at all) to 7 (more than 3 hours), where 1 point means an additional 30 minutes reading on average. It is reasonable to 
think that gaining information can be best described by newspaper reading, however, with diminishing levels of newspaper reading across time, the ESS project stopped asking about both newspaper reading and radio listening. Thus, in the sixth and seventh data rounds, there are no questions on these two aspects. The time spent with watching political content in the television is present in all data rounds, but we consider it a less reliable predictor of high political information. We build this assumption on former research underlining that the amount devoted to television watching - and mainly to commercial channels - has a negative effect on citizens' well-informedness (Aarts \& Semetko, 2003; Ostman \& Parker, 1987). Hence, we decided to run two separate sets of models using either the amount of time spent on reading political news or use the models including political news watching, and we use the latter to check the robustness of our results (see Table 3 in the Supplementary file).

As we assume that the satisfaction gap between government and opposition voters is influenced by sophistication, the effects of primary interest are the interaction effects between voters' government/opposition status and the elements of political sophistication.

- government/opposition status x education

- government/opposition status x political interest

- government/opposition status x political awareness

Therefore, the three sophistication variables are entered in the models both in a simple form and in interaction with voter status.

\section{Control variables}

We used several control variables that may influence satisfaction with the government. This is crucial because the study's aim is to measure the extent of bias, and not the difference in evaluations caused by objectively different conditions, values and preferences. First, we 
included variables on social conditions which can strongly shape objective life conditions, and therefore, also one's perceptions on government policies:

- gender

- $\quad$ the income decile where the household of the respondent belongs to

- $\quad$ the subjective general health of respondents on a 1 to 5 scale

- $\quad$ a dummy variable about self-reported membership of a discriminated group

- a dummy variable about whether the respondent is unemployed

Second, we included variables which can account for a general attitude of satisfaction, optimism and acceptance of the status quo. Therefore, we included

- $\quad$ satisfaction with life, on a 0 to 10 scale

- $\quad$ trust in other people, on a 0 to 10 scale, and we expect a positive effect for both variables.

Third, we included a group of variables on political and religious values that may strongly influence one's satisfaction with a government. Therefore, we included

- $\quad$ the degree of religiousness, on a 0 to 10 scale

- $\quad$ the ideological position on a left-right scale (0 to 10 scale)

Descriptive statistics of the dependent and independent variables and a correlation table of all analysed variables are reported in Table 1 and 2 in the Supplementary file.

\section{Analysis}

In order to answer the research question, we built pooled OLS regressions. As the dataset is a repeated cross-sectional one, we considered country effects and general time trends in political satisfaction across Europe by using country-case fixed effects and by clustering robust standard errors by country-cases. ${ }^{\text {iv }}$ It is important to note that the three elements of sophistication are not 
strongly correlated, for example, education and newspaper reading are practically unrelated to each other $(\mathrm{r}=0.063$; see correlation table in Table 2 in the Supplementary file). The results of the regressions are reported in Table 1.

Table 1

The effect of the interaction of voter status and sophistication on satisfaction with the government.

\begin{tabular}{|c|c|c|c|}
\hline & Model 1 & Model 2 & Model 3 \\
\hline Government voter & $\begin{array}{l}0.353^{*} \\
(0.146)\end{array}$ & $\begin{array}{l}1.289 * * * \\
(0.120)\end{array}$ & $\begin{array}{l}1.142 * * * \\
(0.0864)\end{array}$ \\
\hline Government voter*Political interest & $\begin{array}{c}0.370 * * * \\
(0.064)\end{array}$ & & \\
\hline Government voter*Education & & $\begin{array}{c}0.006 \\
(0.009)\end{array}$ & \\
\hline Government voter*Newspaper reading & & & $\begin{array}{c}0.179 * * * \\
(0.029)\end{array}$ \\
\hline Political interest & $\begin{array}{c}-0.145^{* * *} \\
(0.031)\end{array}$ & $\begin{array}{c}0.034 \\
(0.030)\end{array}$ & $\begin{array}{c}0.034 \\
(0.030)\end{array}$ \\
\hline Education & $\begin{array}{c}0.003 \\
(0.005)\end{array}$ & $\begin{array}{l}-0.001 \\
(0.007)\end{array}$ & $\begin{array}{c}0.003 \\
(0.005)\end{array}$ \\
\hline Newspaper reading & $\begin{array}{c}0.025 \\
(0.024)\end{array}$ & $\begin{array}{c}0.026 \\
(0.024)\end{array}$ & $\begin{array}{l}-0.064 * \\
(0.030)\end{array}$ \\
\hline Life satisfaction & $\begin{array}{c}0.187 * * * \\
(0.008)\end{array}$ & $\begin{array}{c}0.187 * * * \\
(0.008)\end{array}$ & $\begin{array}{c}0.186 * * * \\
(0.008)\end{array}$ \\
\hline Left/right position & $\begin{array}{c}0.091 * * \\
(0.029)\end{array}$ & $\begin{array}{c}0.095^{* *} \\
(0.030)\end{array}$ & $\begin{array}{c}0.094 * * \\
(0.030)\end{array}$ \\
\hline Women & $\begin{array}{c}-0.158 * * * \\
(0.032)\end{array}$ & $\begin{array}{c}-0.160 * * * \\
(0.033)\end{array}$ & $\begin{array}{c}-0.160 * * * \\
(0.032)\end{array}$ \\
\hline Trust in others & $\begin{array}{c}0.133 * * * \\
(0.008)\end{array}$ & $\begin{array}{c}0.133 * * * \\
(0.008)\end{array}$ & $\begin{array}{c}0.133 * * * \\
(0.008)\end{array}$ \\
\hline Religiousness & $\begin{array}{c}0.053 * * * \\
(0.006)\end{array}$ & $\begin{array}{c}0.054 * * * \\
(0.006)\end{array}$ & $\begin{array}{c}0.054 * * * \\
(0.006)\end{array}$ \\
\hline Member of discriminated group & $\begin{array}{c}-0.405^{* * *} * \\
(0.067)\end{array}$ & $\begin{array}{c}-0.413^{* * *} * \\
(0.067)\end{array}$ & $\begin{array}{c}-0.407 * * * \\
(0.067)\end{array}$ \\
\hline Subjective health & $\begin{array}{c}0.022 \\
(0.021)\end{array}$ & $\begin{array}{c}0.025 \\
(0.021)\end{array}$ & $\begin{array}{c}0.025 \\
(0.021)\end{array}$ \\
\hline Household's income & $\begin{array}{l}-0.008 \\
(0.007)\end{array}$ & $\begin{array}{l}-0.008 \\
(0.007)\end{array}$ & $\begin{array}{l}-0.008 \\
(0.007)\end{array}$ \\
\hline Unemployed & $\begin{array}{l}-0.074 \\
(0.051) \\
\end{array}$ & $\begin{array}{l}-0.075 \\
(0.052)\end{array}$ & $\begin{array}{l}-0.077 \\
(0.052) \\
\end{array}$ \\
\hline Constant & $\begin{array}{c}1.181 * * * \\
(0.181)\end{array}$ & $\begin{array}{c}0.710 * * * \\
(0.195)\end{array}$ & $\begin{array}{c}0.785^{* * *} \\
(0.187) \\
\end{array}$ \\
\hline $\begin{array}{l}\text { Number of Observations } \\
\text { Number of Groups }\end{array}$ & & $\begin{array}{c}64558 \\
92\end{array}$ & \\
\hline $\mathrm{F}$ & 181.6 & 177.1 & 254.3 \\
\hline
\end{tabular}


Adjusted R square

0.283

0.279

0.280

Note. Entries are regression coefficients of pooled OLS regressions absorbing country-case effects, with robust standard errors clustered for country-cases. Dependent variable: satisfaction with the government. Sample: First five rounds of ESS: 2002, 2004, 2006, 2008, 2010. Population and design weights applied. For the exact wording of the survey questions see Appendix 2.

$* * * \mathrm{p}<0.001 * * \mathrm{p}<0.01 * \mathrm{p}<0.05$

The significant positive effects show that satisfaction levels of government and opposition supporters are significantly different in the case of more and less interested respondents, and the same applies for more or less heavy political news consumers. Both interest and the time spent on gaining political information widen the satisfaction gap between the two groups. We interpret these differences as an indication of stronger bias for citizens who are interested in politics or who are politically more informed. Contrary to this, the size of the gap between the satisfaction of government and opposition supporters is not affected by the level of education. This result gives support to the claims of Achen and Bartels showing that "the educated, including the highly educated, have gone astray in their moral and political judgments as often as anyone else" (Achen \& Bartels, 2016, p. 310).

The effects of the control variables for which we had prior expectations point to the expected direction, although the effect of health, unemployment and income are insignificant. The effects of the other control variables are highly significant, and the coefficients show notable effect sizes. Being more satisfied with life, having more right-wing ideological views, nurturing more trust in other people and being more religious lead to more satisfaction with the government, while membership in a discriminated group and being a woman have a negative effect on the satisfaction scores.

In Figure 1 to 3, we report the linear predictions for the independent variables (based on the results of Model 1). The satisfaction gap between government and opposition supporters widens both with consuming more political information and with growing levels of political interest to 
reaching the double of the initial difference between the most interested and most informed voting groups.

\section{[Figure 1]}

[Figure 2]

[Figure 3]

We checked the robustness of our results in several ways. Firstly, as we mentioned above, we tested whether it makes a difference if we operationalize political news consumption with news watching (present in 7 data rounds) instead of news reading (present in 5 data rounds). The results show that the two kinds of political information gaining have very similar effect (Table 3 in the Supplementary file). Secondly, a considerable part of former results include identifiers (e. g. Americans who identify themselves as Democrats or Republicans) instead of "voters", therefore we wanted to check whether this kind of alternative operationalization for the independent variable could cause any difference in the results, and we run models operationalizing government support with feeling close to a governing party instead of with voting for a government party. Again, the modification did not produce a notable difference in the results (see Table 4 in the Supplementary file). Thirdly, it is possible to argue that the patterns of media consumption have undergone radical changes in the analysed period, and that the heavy decline of newspaper reading could influence our results. To account for such eventual temporary effects, we run the above models for each ESS round separately (see Table 5 in the Supplementary file). In these models, results are very similar to those reported in the main ones. The interaction effects for political interest and newspaper reading are positive and significant (except for interest in Round 4, which effect is insignificant) and for education, they are insignificant. 
Additionally, the direction and the size of the significant interaction results in Table 1 (government voter $\mathrm{x}$ interest; government voter $\mathrm{x}$ political news watching) are very similar when controlling (or not) for ESS rounds and country dummies, and when the set of control variables is slightly changed. The effect of education is more sensitive to the inclusion or exclusion of controls, but in models with high explanatory power and hence with a smaller number of omitted variables, its effect is consistently insignificant. To sum up, the effects of political interest and political information acquisition are consistently positive and substantial, while education has no individual effect on biased information processing.

\section{Discussion}

The question whether political sophistication decreases partisan bias (and improves the quality of political judgements) is of particular interest for both democratic theory and policymaking as it has primarily important theoretical and empirical implications (Lippmann, 1922). If raising the levels of education and political information fosters people's impartiality and contributes to grounded and rational decisions on an individual level, then these may potentially lead to better political decisions on a societal level. Hence, enhancing the citizenry's sophistication might be a key factor which contributes to the improvement of the quality of democratic functioning. As Dalton highlights, "greater political skills" should enable citizens "to be functionally independent of party cues" (Dalton, 1984, p. 281). Along the lines of this thought, political sophisticates more easily ascertain if their preferred party or politician departs from their promises; they recognize such failures earlier than the less aware and less informed strata of the electorate. Moreover, they may perceive more correctly the real costs of appealing but - in the long run - deleterious policies. Following this line of thought, political sophistication's role might be indispensable in promoting "partisan independence" and warranting well-functioning democratic accountability. 
Not only are these hypotheses normatively appealing, but they are also widely shared by democratic theorists and policymakers. Anyhow, this research offers no support for them. There is no denying that the effect of education on biased opinion-formation is not significant; in other words, educated citizens are neither more, nor less biased opinion formers than less educated ones, but interest and information consumption strongly contribute to bias. Therefore, our findings question the ideas of "sophistication optimists" who praise sophistication and ponder the exclusion of the uninformed stratum of the electorate from the democratic process (e.g, Brennan, 2017).

Taking everything into account, we arrive at the conclusion that taking away the suffrage of uneducated and politically unknowledgeable people does not guarantee the impartial cognition of politics, and therefore it would not significantly improve the quality of democratic decisionmaking. Nevertheless, the assertion on the bias-generating nature of political interest and information consumption which has been recurrently explored in an American context hold in a European one as well. These results reinforce that people who "have a taste for politics" and are politically aware apply more partisan cues and perceive politics in a non-objective manner (Brennan, 2017, p. 40).

\section{Conclusion}

The study clarified the relationship between partisan bias and three aspects of political sophistication on a large, repeated cross-national sample of European voters. This question has long been characterised by contradictory theoretical expectations and divergent empirical 
results. The question of political sophistication is highly important as its effects on the democratic polity are essential in assessing the prerequisites, the scopes, and potential outcomes of the democratic process. The results of the multiple regression models show that political interest and political information acquisition are strongly linked to partisan bias. The third element, education, does not have a significant effect when interest and news consumption are also controlled for.

The paper contributes to the state of the art in three major ways. First, theoretically, both recent optimistic (Brennan, 2017; Somin, 2016) and pessimistic (see especially Achen \& Bartels, 2016) suppositions on the role of sophistication have been partially challenged on the ground of our results. Our findings may help to bring theoretical expectations and the most recent empirical results somewhat closer to each other by showing that education does not exacerbate bias on its own, while political interest and information acquisition leads to more biased views. This implies that when theorizing about the role of sophistication it is worth differentiating between the aspects of sophistication as they appear to play different roles in the creation of bias.

Second, methodologically, the most important contribution of the paper is that it used a novel measurement method to estimate the level of partisan bias in European democracies. On the top of that, the paper significantly contributes to our knowledge on partisanship in the European electorate on which relatively scarce evidence is available because the majority of research focuses on partisan divides between Republicans and Democrats in the context of the United States.

Thirdly, the results have practical relevance as well. Political interest is the most important element - among the examined ones - which significantly contributes to politically biased evaluations. Essentially, this implies that (even among politically engaged citizens) voters with non-partisan thoughts on their minds are the most rational, unbiased information processors. 
However, the fact that education does not make a difference in making citizens more objective in the way they evaluate the political universe, and the effect of more information is positive refutes the idea according to which the suffrage of illiterate citizens should be constrained or taken away. Education does not appear to have a positive effect on more objective political decisions but neither it has a deleterious one. Thus, when assessing the results from the viewpoint of policy-making, it appears that raising awareness and enhancing educational capacities are not the best tools to make citizens' information processing less biased. These results, therefore, do not allow to assume that education and political well-informedness are remedies for all problems connected to the shortcomings of contemporary democracies.

The results, however, also emerge some puzzling questions. We assume that the effect of newspaper reading and television watching on bias may be due to the abundance of partisan messages in media sources and citizens' unconditional adoption of them. Therefore, the mechanism of directional information seeking (Kunda, 1990, p. 481) and confirmation bias (seeking information to support existing predispositions) (Lodge \& Taber, 2005, p. 476) has to be explored further. Additionally, it comes about as an interesting question, as it goes against widely shared expectations, why education proves to be inefficient in fostering more nuanced views. These questions are beyond the scope of this paper but provide fertile ground for future research.

We conclude that the relationship between sophistication and bias is far more complex than it could be described with a simple positive or negative correlation. Therefore, future research concentrating on non-linear relationships between bias and the most important aspects of sophistication could further clarify this central question. The mechanisms underlying selective political perception, the role of interest and the effects of education have to be explored further in order to help the elaboration of both more accurate theories on sophistication and policy programmes for a more enlightened electorate. 


\section{References}

Aarts, K., \& Semetko, H. A. (2003). The divided electorate: Media use and political involvement. Journal of Politics, 65(3), 759-784. https://doi.org/10.1111/14682508.00211

Abramowitz, A. I., \& Saunders, K. L. (2008). Is polarization a myth? The Journal of Politics, 70(02), 542-555. https://doi.org/10.1017/S0022381608080493 
Achen, C. H., \& Bartels, L. M. (2016). Democracy for Realists: Why Elections Do Not Produce Responsive Government. Princeton University Press.

Anderson, C. J., \& LoTempio, A. J. (2002). Winning, losing and political trust in America. British Journal of Political Science, 32(02), 335-351. https://doi.org/10.1017/S0007123402000133

Anderson, C. J., \& Tverdova, Y. V. (2001). Winners, losers, and attitudes about government in contemporary democracies. International Political Science Review, 22(4), 321-338. https://doi.org/10.1177/0192512101022004003

Anduiza, E., Gallego, A., \& Muñoz, J. (2013). Turning a Blind Eye Experimental Evidence of Partisan Bias in Attitudes Toward Corruption. Comparative Political Studies, 46(12), 1664-1692. https://doi.org/10.1177/0010414013489081

Armingeon, K., Isler, C., Knöpfel, L., \& Weisstanner, D. (2016). Supplement to the Comparative Political Data Set - Government Composition 1960-2014. Retrieved from http://www.cpds-data.org/

Bartels, L. M. (2002). Beyond the running tally: Partisan bias in political perceptions. Political Behavior, 24(2), 117-150. https://doi.org/10.1023/A:1021226224601

Bisgaard, M. (2015). Bias will find a way: Economic perceptions, attributions of blame, and partisan-motivated reasoning during crisis. The Journal of Politics, 77(3), 849-860.

Blais, A., \& Gélineau, F. (2007). Winning, losing and satisfaction with democracy. Political Studies, 55(2), 425-441. https://doi.org/10.1111/j.1467-9248.2007.00659

Brennan, J. (2009). Polluting the polls: When citizens should not vote. Australasian Journal of Philosophy, 87(4), 535-549. https://doi.org/10.1080/00048400802587309

Brennan, J. (2017). Against democracy. Princeton University Press.

Brunell, T. L., \& Buchler, J. (2012). How Does Winning, Losing, and Electoral Competitiveness Affect Voters' Attitudes Toward Government? Evidence from Three 
Western Democracies. Evidence from Three Western Democracies. Retrieved from http://papers.ssrn.com/sol3/papers.cfm?abstract_id=2108176

Campbell, A., Converse, P. E., Miller, W. E., \& Stokes, D. E. (1960). The American Voter. New York and London: John Wiley \& Sons, Inc.

Caplan, B. (2011). The myth of the rational voter: Why democracies choose bad policies. Princeton University Press.

Converse, P. E. (2006). The nature of belief systems in mass publics (1964). Critical Review, 18(1-3), 1-74. https://doi.org/DOI: 10.1080/08913810608443650

Craig, S. C., Martinez, M. D., Gainous, J., \& Kane, J. G. (2006). Winners, losers, and election context: Voter responses to the 2000 presidential election. Political Research Quarterly, 59(4), 579-592. https://doi.org/10.1177/106591290605900407

Curini, L., Jou, W., \& Memoli, V. (2012). Satisfaction with democracy and the winner/loser debate: The role of policy preferences and past experience. British Journal of Political Science, 42(02), 241-261. https://doi.org/10.1017/S0007123411000275

Dalton, R. J. (1984). Cognitive mobilization and partisan dealignment in advanced industrial democracies. The Journal of Politics, 46(01), 264-284. http://dx.doi.org/10.2307/2130444

Dalton, R. J. (2007). Partisan mobilization, cognitive mobilization and the changing American electorate. Electoral Studies, 26(2), 274-286.

Druckman, J. N., \& Lupia, A. (2000). Preference formation. Annual Review of Political Science, 3(1), 1-24. https://doi.org/10.1146/annurev.polisci.3.1.1

European Social Survey. (2015). European Social Survey Round 1 to 7. Norwegian Centre for Research Data, Norway - Data Archive and distributor of ESS data for ESS ERIC. 
Eveland, W. P., \& Scheufele, D. A. (2000). Connecting news media use with gaps in knowledge and participation. Political Communication, 17(3), 215-237. https://doi.org/10.1080/105846000414250

Flynn, D. J. (2016). The scope and correlates of political misperceptions in the mass public. Annual Meeting of the American Political Science Association, Philadelphia.

Flynn, D. J., Nyhan, B., \& Reifler, J. (2017). The nature and origins of misperceptions: Understanding false and unsupported beliefs about politics. Political Psychology, 38(S1), 127-150. https://doi.org/10.1111/pops.12394

Hill, L. (2016). Voting turnout, equality, liberty and representation: Epistemic versus procedural democracy. Critical Review of International Social and Political Philosophy, 19(3), 283-300. https://doi.org/10.1080/13698230.2016.1144855

Howell, P., \& Justwan, F. (2013). Nail-biters and no-contests: The effect of electoral margins on satisfaction with democracy in winners and losers. Electoral Studies, 32(2), 334 343. https://doi.org/10.1016/j.electstud.2013.02.004

Jerit, J., \& Barabas, J. (2012). Partisan perceptual bias and the information environment. Journal of Politics, 74(3), 672-684. https://doi.org/doi:10.1017/S0022381612000187 Joslyn, M. R., \& Haider-Markel, D. P. (2014). Who knows best? Education, partisanship, and contested facts. Politics \& Policy, 42(6), 919-947. https://doi.org/10.1111/polp.12098

Kahne, J., \& Bowyer, B. (2017). Educating for democracy in a partisan age: Confronting the challenges of motivated reasoning and misinformation. American Educational Research Journal, 54(1), 3-34. https://doi.org/10.3102/0002831216679817

Kunda, Z. (1990). The case for motivated reasoning. Psychological Bulletin, 108(3), 480. Lippmann, W. (1922). Public Opinion. New York.

Lodge, M., \& Hamill, R. (1986). A partisan schema for political information processing. The American Political Science Review, 505-520. https://doi.org/10.2307/1958271 
Lodge, M., \& Taber, C. S. (2005). The automaticity of affect for political leaders, groups, and issues: An experimental test of the hot cognition hypothesis. Political Psychology, 26(3), 455-482. https://doi.org/10.1111/j.1467-9221.2005.00426.x

Luskin, R. C. (1990). Explaining Political Sophistication. Political Behavior, 12(4), 331-361. http://dx.doi.org/10.1007/BF00992793

Ostman, R. E., \& Parker, J. L. (1987). Impact of education, age, newspapers, and television on environmental knowledge, concerns, and behaviors. The Journal of Environmental Education, 19(1), 3-9. https://doi.org/10.1080/00958964.1987.10801954

Shani, D. (2006). Knowing Your Colors: Can Knowledge Correct for Partisan Bias in Political Perceptions? Presented at the Annual Meeting of the Midwest Political Science Association.

Singh, S., Karakoç, E., \& Blais, A. (2012). Differentiating winners: How elections affect satisfaction with democracy. Electoral Studies, 31(1), 201-211. https://doi.org/dx.doi.org/10.1016/j.electstud.2011.11.001

Singh, S., Lago, I., \& Blais, A. (2011). Winning and Competitiveness as Determinants of Political Support*. Social Science Quarterly, 92(3), 695-709. https://doi.org/10.1111/j.1540-6237.2011.00788.x

Somin, I. (2016). Democracy and political ignorance: Why smaller government is smarter. Stanford University Press.

Taber, C. S., Cann, D., \& Kucsova, S. (2009). The Motivated Processing of Political Arguments. Political Behavior, 31(2), 137-155. https://doi.org/10.1007/s11109-008$9075-8$

Taber, C. S., \& Lodge, M. (2006). Motivated skepticism in the evaluation of political beliefs. American Journal of Political Science, 50(3), 755-769. https://doi.org/10.1111/j.15405907.2006.00214.x 
Tesler, M. (2018). Elite domination of public doubts about climate change (not evolution). Political Communication, 35(2), 306-326. https://doi.org/10.1080/10584609.2017.1380092

Tilley, J., \& Hobolt, S. B. (2011). Is the government to blame? An experimental test of how partisanship shapes perceptions of performance and responsibility. The Journal of Politics, 73(02), 316-330. https://doi.org/doi:10.1017/S0022381611000168

Wagner, M., Tarlov, J., \& Vivyan, N. (2014). Partisan bias in opinion formation on episodes of political controversy: Evidence from Great Britain. Political Studies, 62(1), 136158. https://doi.org/10.1111/j.1467-9248.2012.01002.x

Zaller, J. (1992). The nature and origins of mass opinion. Cambridge University Press. 


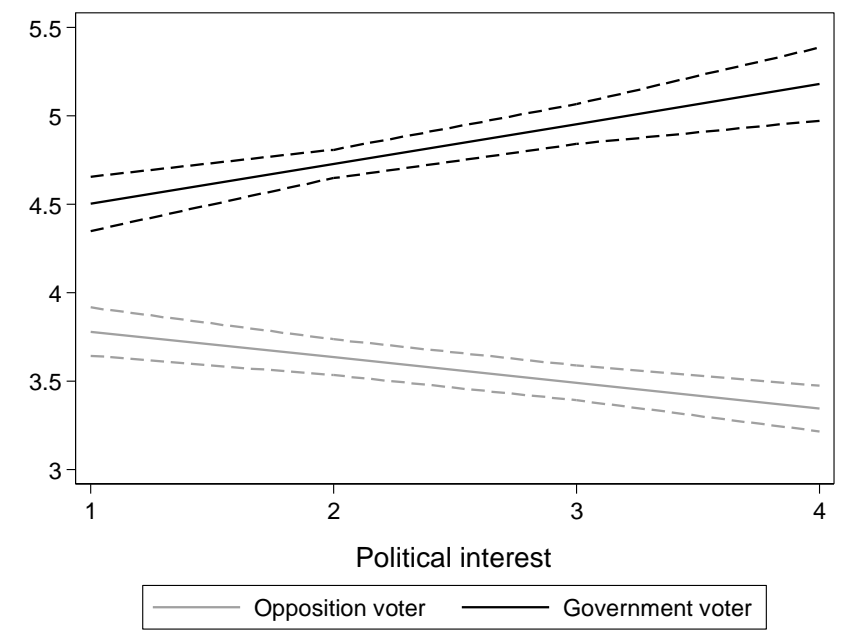

FIGURE 1.

Predictive margins of voters' government/opposition status with a 95\% confidence interval, with regard to political interest. Dependent variable is satisfaction with the government, ranging from 0 to 10. Predictions for government voters are indicated with black, predictions for opposition voters are indicated with grey.

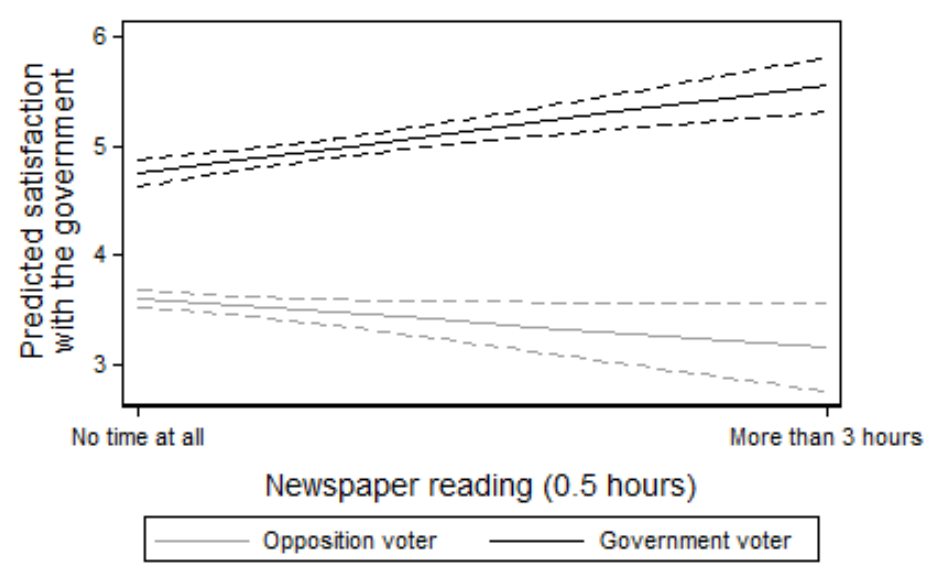

\section{FIGURE 2.}

Predictive margins of voters' government/opposition status with a 95\% confidence interval, with regard to newspaper reading. Dependent variable is satisfaction with the government, ranging from 0 to 10 . Predictions for government voters are indicated with black, predictions for opposition voters are indicated with grey. 


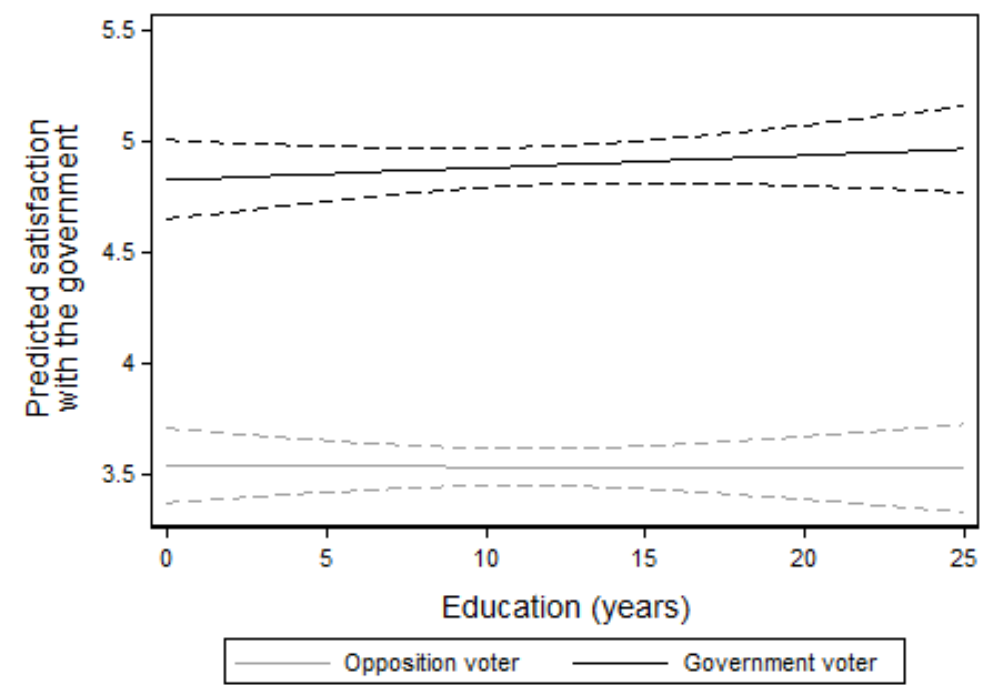

FIGURE 3.

Predictive margins of voters' government/opposition status with a 95\% confidence interval, with regard to education. Dependent variable is satisfaction with the government, ranging from 0 to 10. Predictions for government voters are indicated with black, predictions for opposition voters are indicated with grey. 
Appendix 1.

Country-cases included in the analysis.

\begin{tabular}{|c|c|c|c|c|c|c|c|}
\hline & 2002 & 2004 & 2006 & 2008 & 2010 & 2012 & 2014 \\
\hline Austria & $*$ & $*$ & $*$ & & & & $*$ \\
\hline Belgium & $*$ & $*$ & $*$ & $*$ & $*$ & $*$ & \\
\hline Bulgaria & & & $*$ & $*$ & $*$ & $*$ & \\
\hline Croatia & & & & $*$ & & & \\
\hline Cyprus & & & $*$ & $*$ & & $*$ & \\
\hline Czech Republic & $*$ & $*$ & & & $*$ & $*$ & $*$ \\
\hline Denmark & $*$ & $*$ & $*$ & $*$ & $*$ & $*$ & $*$ \\
\hline Estonia & & $*$ & & $*$ & & $*$ & $*$ \\
\hline Finland & $*$ & $*$ & $*$ & $*$ & $*$ & $*$ & $*$ \\
\hline France & $*$ & $*$ & $*$ & $*$ & $*$ & $*$ & $*$ \\
\hline Germany & & $*$ & $*$ & $*$ & $*$ & $*$ & $*$ \\
\hline Greece & $*$ & $*$ & & & $*$ & & \\
\hline Hungary & $*$ & $*$ & $*$ & $*$ & $*$ & $*$ & $*$ \\
\hline Iceland & & $*$ & & & & $*$ & \\
\hline Ireland & $*$ & $*$ & & $*$ & $*$ & $*$ & $*$ \\
\hline Italy & $*$ & & & & & $*$ & \\
\hline Latvia & & & & $*$ & & & \\
\hline Lithuania & & & & & $*$ & $*$ & $*$ \\
\hline Luxemburg & $*$ & $*$ & & & & & \\
\hline Netherlands & $*$ & $*$ & & $*$ & & & $*$ \\
\hline Norway & $*$ & $*$ & $*$ & $*$ & $*$ & $*$ & $*$ \\
\hline Poland & $*$ & $*$ & $*$ & $*$ & $*$ & $*$ & $*$ \\
\hline Portugal & $*$ & & $*$ & $*$ & $*$ & $*$ & \\
\hline Romania & & & & $*$ & & & \\
\hline Slovakia & & $*$ & $*$ & $*$ & $*$ & $*$ & \\
\hline Slovenia & $*$ & & $*$ & $*$ & $*$ & $*$ & $*$ \\
\hline Spain & $*$ & $*$ & $*$ & $*$ & $*$ & $*$ & $*$ \\
\hline Sweden & & $*$ & $*$ & $*$ & $*$ & $*$ & \\
\hline Switzerland & $*$ & $*$ & $*$ & $*$ & $*$ & $*$ & $*$ \\
\hline United Kingdom & $*$ & * & $*$ & $*$ & * & $*$ & \\
\hline
\end{tabular}




\section{Appendix 2.}

The exact wording of the survey questions analysed.

Satisfaction with the government. Now thinking about the [national] government,, how satisfied are you with the way it is doing its job?

Government voter. Which party did you vote for in that election? (Recoded into categories of government/opposition supporters.)

Education. About how many years of education have you completed, whether full-time or parttime? Please report these in full-time equivalents and include compulsory years of schooling. Political interest. How interested would you say you are in politics?

Newspaper reading. And how much of this time is spent reading about politics and current affairs?

$T v$ watching. And again on an average weekday, how much of your time watching television is spent watching news or programmes about politics and current affairs1?

Life satisfaction. All things considered, how satisfied are you with your life as a whole nowadays?

Left/right position. In politics people sometimes talk of "left" and "right". Using this card, where would you place yourself on this scale, where 0 means the left and 10 means the right? Religiousness. Regardless of whether you belong to a particular religion, how religious would you say you are?

Trust in others. Using this card, generally speaking, would you say that most people can be trusted, or that you can't be too careful in dealing with people? Please tell me on a score of 0 to 10 , where 0 means you can't be too careful and 10 means that most people can be trusted. Member of discriminated group. Would you describe yourself as being a member of a group that is discriminated against in this country?

Health. How is your health in general? Would you say it is... 
Unemployed. And which of these descriptions best describes your situation (in the last seven days)? Please select only one (both "unemployed and actively looking for a job" and "unemployed, wanting a job but not actively looking for a job" are considered). 


\section{Supplementary file}

Table 1

Descriptive statistics of the dependent and independent variables (first seven rounds: 2002, 2004, 2006, 2008, 2010, 2012, 2014).

\begin{tabular}{lccccccc} 
& N of & \multicolumn{3}{c}{ Original variable } & \multicolumn{3}{c}{ Standardized form } \\
& observations & Mean & Std. D. & Min. & Max. & Min. & Max. \\
\hline Satisfaction with the government & 250608 & 4.171 & 2.463 & 0 & 10 & & \\
Voted for a government party & 157077 & 0.513 & 0.5 & 0 & 1 & & \\
Feels close to a government party & 125703 & 0.437 & 0.496 & 0 & 1 & & \\
Woman & 260806 & 0.535 & 0.499 & 0 & 1 & & \\
Member of discriminated group & 258846 & 0.064 & 0.245 & 0 & 1 & & \\
Unemployed & 260894 & 0.066 & 0.248 & 0 & 1 & & \\
Political interest & 260160 & 2.627 & 0.902 & 1 & 4 & -1.523 & 1.805 \\
Years spent in education & 260894 & 12.228 & 4.05 & 0 & 35 & -3.019 & 5.622 \\
Political newspaper reading & 135088 & 1.202 & 0.882 & 0 & 7 & -1.362 & 6.572 \\
Political tv content viewing & 251187 & 1.968 & 1.313 & 0 & 7 & -1.498 & 3.832 \\
Age & 260894 & 47.888 & 18.485 & 13 & 100 & -1.887 & 2.819 \\
Satisfaction with life & 259800 & 6.921 & 2.283 & 0 & 10 & -3.032 & 1.349 \\
Left-right ideological position & 226986 & 5.09 & 2.174 & 0 & 10 & -2.341 & 2.258 \\
Trust in other people & 260062 & 5.026 & 2.448 & 0 & 10 & -2.053 & 2.032 \\
Religiousness & 258859 & 4.722 & 2.994 & 0 & 10 & -1.577 & 1.763 \\
Health status & 260652 & 3.793 & 0.925 & 1 & 5 & -3.02 & 1.306 \\
Income decile & 193963 & 5.664 & 2.735 & 1 & 10 & -1.705 & 1.586 \\
\hline
\end{tabular}


Table 2

Correlation table of the variables analysed (first five rounds: 2002, 2004, 2006, 2008, 2010).

\begin{tabular}{|c|c|c|c|c|c|c|c|c|c|c|c|c|c|c|c|c|}
\hline & 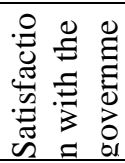 & 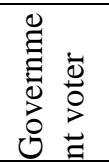 & 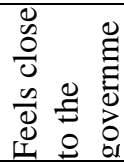 & 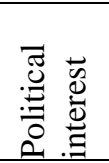 & 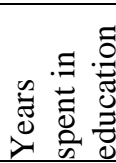 & 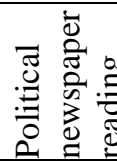 & 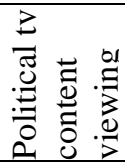 & 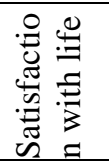 & 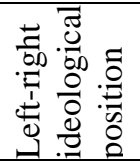 & 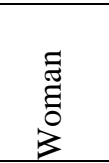 & 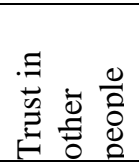 & 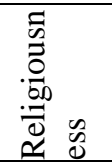 & 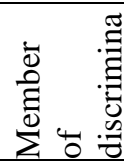 & 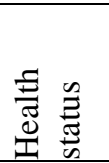 & 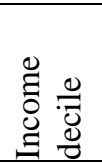 & 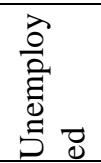 \\
\hline Satisfaction with the government & 1 & & & & & & & & & & & & & & & \\
\hline Government voter & 0.382 & 1 & & & & & & & & & & & & & & \\
\hline Feels close to the government & 0.357 & 0.809 & 1 & & & & & & & & & & & & & \\
\hline Political interest & 0.035 & 0.004 & 0.005 & 1 & & & & & & & & & & & & \\
\hline Years spent in education & 0.014 & -0.028 & -0.015 & 0.212 & 1 & & & & & & & & & & & \\
\hline Political newspaper reading & 0.041 & 0.01 & 0.009 & 0.281 & 0.063 & 1 & & & & & & & & & & \\
\hline Political tv content viewing & -0.001 & -0.019 & -0.027 & 0.191 & -0.117 & 0.276 & 1 & & & & & & & & & \\
\hline Satisfaction with life & 0.292 & 0.062 & 0.058 & 0.077 & 0.073 & 0.046 & -0.03 & 1 & & & & & & & & \\
\hline Left-right ideological position & 0.198 & 0.143 & 0.12 & -0.036 & -0.036 & 0.004 & 0.011 & 0.127 & 1 & & & & & & & \\
\hline Woman & -0.038 & -0.001 & -0.003 & -0.134 & -0.009 & -0.087 & -0.05 & 0.008 & -0.036 & 1 & & & & & & \\
\hline Trust in other people & 0.227 & -0.009 & -0.005 & 0.1 & 0.164 & 0.054 & -0.024 & 0.305 & 0.006 & 0 & 1 & & & & & \\
\hline Religiousness & 0.114 & 0.084 & 0.077 & -0.021 & -0.12 & 0.003 & 0.028 & 0.064 & 0.203 & 0.157 & -0.014 & 1 & & & & \\
\hline Member of discriminated group & -0.089 & -0.056 & -0.053 & 0.049 & 0.053 & 0.015 & 0.018 & -0.1 & -0.046 & 0.016 & -0.044 & -0.012 & 1 & & & \\
\hline Health status & 0.125 & 0.019 & 0.022 & 0.059 & 0.213 & -0.012 & -0.128 & 0.315 & 0.057 & -0.036 & 0.186 & -0.05 & -0.049 & 1 & & \\
\hline Income decile & 0.126 & 0.026 & 0.035 & 0.136 & 0.318 & 0.038 & -0.098 & 0.262 & 0.043 & -0.088 & 0.212 & -0.103 & -0.022 & 0.266 & 1 & \\
\hline Unemployed & -0.067 & -0.026 & -0.032 & -0.029 & -0.01 & -0.022 & 0.008 & -0.154 & -0.038 & 0 & -0.055 & -0.023 & 0.053 & -0.021 & -0.112 & \\
\hline
\end{tabular}


Table 3

The effect of the interaction of voter status and sophistication on satisfaction with the government in the first seven rounds (2002, 2004, 2006, 2008, 2010, 2012, 2014).

\begin{tabular}{|c|c|c|c|}
\hline Government voter & $\begin{array}{l}1.096 * * * \\
(0.0921)\end{array}$ & $\begin{array}{l}0.571 * * * \\
\quad(0.117)\end{array}$ & $\begin{array}{l}1.524 * * * \\
\quad(0.118)\end{array}$ \\
\hline Government voter*Tv watching & $\begin{array}{l}0.136 * * * \\
(0.0192)\end{array}$ & & \\
\hline Government voter*Political interest & & $\begin{array}{c}0.304 * * * \\
(0.0477)\end{array}$ & \\
\hline Government voter*Education & & & $\begin{array}{c}-0.0108 \\
(0.00773)\end{array}$ \\
\hline Political interest & $\begin{array}{c}0.0417 * \\
(0.0194)\end{array}$ & $\begin{array}{c}-0.0992 * * * \\
(0.0248)\end{array}$ & $\begin{array}{l}0.0427 * \\
(0.0193)\end{array}$ \\
\hline Education & $\begin{array}{l}-0.00171 \\
(0.00365)\end{array}$ & $\begin{array}{l}-0.00139 \\
(0.00369)\end{array}$ & $\begin{array}{c}0.00349 \\
(0.00537)\end{array}$ \\
\hline Tv watching & $\begin{array}{l}-0.0179 \\
(0.0132)\end{array}$ & $\begin{array}{l}0.0462 * * * \\
(0.00953)\end{array}$ & $\begin{array}{r}0.0473 * * * \\
(0.00967)\end{array}$ \\
\hline Life satisfaction & $\begin{array}{l}0.184 * * * \\
(0.00642)\end{array}$ & $\begin{array}{l}0.185 * * * \\
(0.00634)\end{array}$ & $\begin{array}{l}0.185^{* * * *} \\
(0.00634)\end{array}$ \\
\hline Left/right position & $\begin{array}{l}0.0745^{* *} \\
(0.0250)\end{array}$ & $\begin{array}{c}0.0725^{* *} \\
(0.0251)\end{array}$ & $\begin{array}{c}0.0752 * * \\
(0.0252)\end{array}$ \\
\hline Women & $\begin{array}{l}-0.118 * * * \\
(0.0230)\end{array}$ & $\begin{array}{c}-0.113 * * * \\
(0.0231)\end{array}$ & $\begin{array}{c}-0.119 * * * \\
(0.0232)\end{array}$ \\
\hline Trust in others & $\begin{array}{l}0.141 * * * \\
(0.00595)\end{array}$ & $\begin{array}{l}0.141 * * * \\
(0.00582)\end{array}$ & $\begin{array}{l}0.141 * * * \\
(0.00597)\end{array}$ \\
\hline Religiousness & $\begin{array}{l}0.0528 * * * \\
(0.00522)\end{array}$ & $\begin{array}{l}0.0523 * * * \\
(0.00517)\end{array}$ & $\begin{array}{r}0.0528 * * * \\
(0.00525)\end{array}$ \\
\hline Discriminated & $\begin{array}{l}-0.450 * * * \\
(0.0478)\end{array}$ & $\begin{array}{c}-0.445^{* * *} \\
(0.0477)\end{array}$ & $\begin{array}{c}-0.451 * * * \\
(0.0475)\end{array}$ \\
\hline Health & $\begin{array}{l}0.0549 * * * \\
(0.0158)\end{array}$ & $\begin{array}{c}0.0534 * * \\
(0.0160)\end{array}$ & $\begin{array}{c}0.0550 * * * * \\
(0.0157)\end{array}$ \\
\hline Income & $\begin{array}{l}-0.000400 \\
(0.00639)\end{array}$ & $\begin{array}{l}-0.00149 \\
(0.00631)\end{array}$ & $\begin{array}{r}-0.000763 \\
(0.00636)\end{array}$ \\
\hline Unemployed & $\begin{array}{l}-0.0792 \\
(0.0451)\end{array}$ & $\begin{array}{l}-0.0799 \\
(0.0451)\end{array}$ & $\begin{array}{l}-0.0798 \\
(0.0453)\end{array}$ \\
\hline Constant & $\begin{array}{l}0.631 * * * \\
(0.155)\end{array}$ & $\begin{array}{c}0.883 * * * \\
(0.157)\end{array}$ & $\begin{array}{l}0.418 * \\
(0.164)\end{array}$ \\
\hline $\begin{array}{l}\text { Observations } \\
\text { Adjusted R square }\end{array}$ & $\begin{array}{l}113877 \\
0.298\end{array}$ & $\begin{array}{c}113877 \\
0.300\end{array}$ & $\begin{array}{c}113877 \\
0.297\end{array}$ \\
\hline
\end{tabular}

Entries are regression coefficients of pooled OLS regressions absorbing country-case effects, with robust standard errors clustered for country-cases. Dependent variable: satisfaction with the government. Political awareness is proxied with the daily amount of watching political content in television. Population and design weights applied.

$* * * \mathrm{p}<0.001 * * \mathrm{p}<0.01 * \mathrm{p}<0.05$ 
Table 4

The effect of the interaction of voter status and sophistication on satisfaction with the government in the first five rounds (2002, 2004, 2006, 2008, 2010).

\begin{tabular}{|c|c|c|c|}
\hline Government identifier & $\begin{array}{c}1.416^{* * * *} \\
(0.124)\end{array}$ & $\begin{array}{c}0.785 * * * \\
(0.184)\end{array}$ & $\begin{array}{c}1.526^{* * *} * \\
(0.170)\end{array}$ \\
\hline Government identifier*Newspaper reading & $\begin{array}{c}0.149 * * * \\
(0.0361)\end{array}$ & & \\
\hline Government identifier*Interest & & $\begin{array}{c}0.290 * * * \\
(0.0824)\end{array}$ & \\
\hline Government identifier*Education & & & $\begin{array}{l}0.00618 \\
(0.0102)\end{array}$ \\
\hline Interest & $\begin{array}{l}-0.0002 \\
(0.0332)\end{array}$ & $\begin{array}{l}-0.122 * * \\
(0.0410)\end{array}$ & $\begin{array}{l}-0.0004 \\
(0.0334)\end{array}$ \\
\hline Education & $\begin{array}{c}0.00152 \\
(0.00502)\end{array}$ & $\begin{array}{c}0.00191 \\
(0.00498)\end{array}$ & $\begin{array}{l}-0.00113 \\
(0.00633)\end{array}$ \\
\hline Newspaper reading & $\begin{array}{l}-0.0483 \\
(0.0302)\end{array}$ & $\begin{array}{c}0.0158 \\
(0.0245)\end{array}$ & $\begin{array}{c}0.0158 \\
(0.0249)\end{array}$ \\
\hline Life satisfaction & $\begin{array}{l}0.166 * * * \\
(0.00990)\end{array}$ & $\begin{array}{l}0.167 * * * \\
(0.00995)\end{array}$ & $\begin{array}{c}0.166 * * * \\
(0.0100)\end{array}$ \\
\hline Left/right position & $\begin{array}{c}0.0997 * * \\
(0.0351)\end{array}$ & $\begin{array}{c}0.0976^{* *} \\
(0.0350)\end{array}$ & $\begin{array}{c}0.0999 * * \\
(0.0351)\end{array}$ \\
\hline Women & $\begin{array}{c}-0.152 * * * \\
(0.0281)\end{array}$ & $\begin{array}{c}-0.149 * * * \\
(0.0278)\end{array}$ & $\begin{array}{c}-0.151 * * * \\
(0.0281)\end{array}$ \\
\hline Trust in others & $\begin{array}{l}0.127 * * * \\
(0.00916)\end{array}$ & $\begin{array}{l}0.126 * * * \\
(0.00906)\end{array}$ & $\begin{array}{c}0.127^{* * *} \\
(0.00907)\end{array}$ \\
\hline Religiousness & $\begin{array}{c}0.0633 * * * \\
(0.00717)\end{array}$ & $\begin{array}{c}0.0627 * * * \\
(0.00712)\end{array}$ & $\begin{array}{c}0.0632 * * * \\
(0.00717)\end{array}$ \\
\hline Discriminated & $\begin{array}{c}-0.431 * * * \\
(0.0713)\end{array}$ & $\begin{array}{c}-0.428 * * * \\
(0.0711)\end{array}$ & $\begin{array}{c}-0.435 * * * \\
(0.0704)\end{array}$ \\
\hline Health & $\begin{array}{c}0.0436 \\
(0.0293)\end{array}$ & $\begin{array}{c}0.0429 \\
(0.0295)\end{array}$ & $\begin{array}{c}0.0439 \\
(0.0293)\end{array}$ \\
\hline Income & $\begin{array}{c}0.00187 \\
(0.00864)\end{array}$ & $\begin{array}{l}0.000785 \\
(0.00879)\end{array}$ & $\begin{array}{c}0.00156 \\
(0.00848)\end{array}$ \\
\hline Unemployed & $\begin{array}{r}-0.00689 \\
(0.0535) \\
\end{array}$ & $\begin{array}{l}-0.0119 \\
(0.0512) \\
\end{array}$ & $\begin{array}{c}-0.00806 \\
(0.0534) \\
\end{array}$ \\
\hline Constant & $\begin{array}{c}0.964 * * * \\
(0.222)\end{array}$ & $\begin{array}{c}1.238 * * * \\
(0.215)\end{array}$ & $\begin{array}{c}0.917 * * * \\
(0.217)\end{array}$ \\
\hline Observations & 51512 & 51512 & 51512 \\
\hline Adjusted R square & 0.288 & 0.290 & 0.287 \\
\hline
\end{tabular}

Entries are regression coefficients of pooled OLS regressions absorbing country-case effects, with robust standard errors clustered for country-cases. Dependent variable: satisfaction with the government. Independent variable: feeling close to a government party. Population and design weights applied.

$* * * \mathrm{p}<0.001 * * \mathrm{p}<0.01 * \mathrm{p}<0.05$ 
Table 5

The effect of the interaction of voter status and political news reading on satisfaction with the government in the first five ESS data rounds (2002, 2004, 2006, 2008, 2010).

\begin{tabular}{|c|c|c|c|c|c|}
\hline & \multicolumn{5}{|c|}{ Newspaper reading } \\
\hline & Round 1 & Round 2 & Round 3 & Round 4 & Round 5 \\
\hline \multirow[t]{2}{*}{ Government voter } & $1.230 * * *$ & $1.026 * * *$ & $0.917 * * *$ & $1.228 * * *$ & $1.203 * * *$ \\
\hline & $(0.164)$ & $(0.0890)$ & $(0.171)$ & $(0.250)$ & $(0.198)$ \\
\hline \multirow{2}{*}{$\begin{array}{l}\text { Government voter*Newspaper } \\
\text { reading }\end{array}$} & $0.260 *$ & $0.133 *$ & $0.250 * * *$ & $0.0891 * *$ & $0.198 * *$ \\
\hline & $(0.113)$ & $(0.0504)$ & $(0.0373)$ & $(0.0246)$ & $(0.0573)$ \\
\hline \multirow[t]{2}{*}{ Interest } & 0.0637 & -0.0249 & 0.0117 & 0.0783 & 0.0372 \\
\hline & $(0.0432)$ & $(0.0577)$ & $(0.0869)$ & $(0.0646)$ & $(0.0533)$ \\
\hline \multirow[t]{2}{*}{ Education } & 0.00257 & 0.00502 & 0.00422 & 0.0113 & -0.0116 \\
\hline & $(0.0134)$ & $(0.00605)$ & $(0.0102)$ & (0.0100) & (0.0119) \\
\hline \multirow[t]{2}{*}{ Newspaper reading } & -0.133 & -0.00885 & -0.108 & -0.0181 & -0.0689 \\
\hline & $(0.0645)$ & $(0.0657)$ & $(0.0766)$ & $(0.0388)$ & $(0.0597)$ \\
\hline \multirow[t]{2}{*}{ Life satisfaction } & $0.162 * * *$ & $0.180 * * *$ & $0.177 * * *$ & $0.201 * * *$ & $0.195 * * *$ \\
\hline & $(0.0212)$ & $(0.0155)$ & $(0.0188)$ & $(0.0176)$ & $(0.0154)$ \\
\hline \multirow[t]{2}{*}{ Left/right position } & 0.0853 & 0.0123 & 0.0873 & 0.110 & $0.164 *$ \\
\hline & $(0.0660)$ & $(0.0329)$ & $(0.0612)$ & $(0.0750)$ & $(0.0765)$ \\
\hline \multirow[t]{2}{*}{ Women } & $-0.284 * *$ & -0.124 & $-0.225^{* *}$ & -0.130 & $-0.0864 *$ \\
\hline & $(0.0741)$ & $(0.0833)$ & $(0.0573)$ & $(0.0712)$ & $(0.0345)$ \\
\hline \multirow[t]{2}{*}{ Trust in others } & $0.124 * * *$ & $0.152 * * *$ & $0.123 * * *$ & $0.146 * * *$ & $0.114 * * *$ \\
\hline & $(0.0246)$ & $(0.00649)$ & $(0.0113)$ & (0.0187) & $(0.0171)$ \\
\hline \multirow[t]{2}{*}{ Religiousness } & $0.0740 * * *$ & $0.0520 * * *$ & $0.0548 * * *$ & $0.0630 * * *$ & $0.0348 *$ \\
\hline & $(0.0180)$ & $(0.0107)$ & $(0.0110)$ & $(0.0132)$ & $(0.0121)$ \\
\hline \multirow[t]{2}{*}{ Discriminated } & $-0.560 * *$ & $-0.523 * *$ & $-0.428 * *$ & $-0.404 * * *$ & -0.179 \\
\hline & $(0.166)$ & $(0.181)$ & $(0.146)$ & $(0.0650)$ & $(0.0931)$ \\
\hline \multirow[t]{2}{*}{ Health } & 0.0431 & -0.00380 & -0.00927 & 0.0347 & 0.0640 \\
\hline & $(0.0496)$ & $(0.0363)$ & $(0.0726)$ & (0.0199) & $(0.0384)$ \\
\hline \multirow[t]{2}{*}{ Income } & -0.00303 & -0.0221 & $-0.0393 *$ & -0.00394 & 0.00744 \\
\hline & $(0.0135)$ & (0.0126) & $(0.0149)$ & $(0.0180)$ & $(0.0107)$ \\
\hline \multirow[t]{2}{*}{ Unemployed } & -0.0745 & -0.176 & -0.0556 & -0.121 & 0.0289 \\
\hline & $(0.103)$ & $(0.0897)$ & $(0.191)$ & $(0.0720)$ & $(0.0543)$ \\
\hline \multirow[t]{2}{*}{ Constant } & $0.936^{* *}$ & $1.593 * * *$ & $1.479 * * *$ & 0.116 & 0.238 \\
\hline & $(0.303)$ & $(0.265)$ & $(0.180)$ & $(0.250)$ & $(0.522)$ \\
\hline Observations & 10541 & 14465 & 12067 & 14648 & 12837 \\
\hline Adjusted R square & 0.270 & 0.258 & 0.254 & 0.294 & 0.324 \\
\hline
\end{tabular}

Entries are regression coefficients of OLS regressions absorbing country-case effects. with robust standard errors clustered for country-cases, separetely run for ESS rounds 1-5. Dependent variable: satisfaction with the government. Population and design weights applied.

$* * * \mathrm{p}<0.001 * * \mathrm{p}<0.01 * \mathrm{p}<0.05$

Table 6 
The effect of the interaction of voter status and interest on satisfaction with the government in the first five ESS data rounds (2002, 2004, 2006, 2008, 2010).

\begin{tabular}{|c|c|c|c|c|c|}
\hline & \multicolumn{5}{|c|}{ Interest } \\
\hline & Round 1 & Round 2 & Round 3 & Round 4 & Round 5 \\
\hline \multirow[t]{2}{*}{ Government voter } & 0.478 & 0.0880 & 0.689 & 0.115 & $0.486^{* *}$ \\
\hline & $(0.264)$ & $(0.162)$ & $(0.448)$ & $(0.284)$ & $(0.153)$ \\
\hline \multirow[t]{2}{*}{ Government voter*Interest } & $0.407^{* *}$ & $0.407 * * *$ & 0.198 & $0.440 * *$ & $0.348^{* *}$ \\
\hline & $(0.123)$ & $(0.0625)$ & $(0.203)$ & $(0.126)$ & $(0.0991)$ \\
\hline \multirow[t]{2}{*}{ Interest } & -0.133 & $-0.205^{* *}$ & -0.0902 & -0.150 & $-0.121^{* *}$ \\
\hline & $(0.0893)$ & $(0.0577)$ & $(0.0631)$ & $(0.0941)$ & $(0.0344)$ \\
\hline \multirow[t]{2}{*}{ Education } & 0.00431 & 0.00524 & 0.00320 & 0.0125 & -0.0114 \\
\hline & $(0.0138)$ & $(0.00562)$ & $(0.0104)$ & $(0.00977)$ & $(0.0117)$ \\
\hline \multirow[t]{2}{*}{ Newspaper reading } & -0.0150 & 0.0569 & 0.0208 & 0.0295 & 0.0218 \\
\hline & $(0.0285)$ & $(0.0475)$ & $(0.0781)$ & $(0.0459)$ & $(0.0464)$ \\
\hline \multirow[t]{2}{*}{ Life satisfaction } & $0.164 * * *$ & $0.181 * * *$ & $0.179 * * *$ & $0.203 * * *$ & $0.196^{* * *}$ \\
\hline & $(0.0226)$ & $(0.0144)$ & $(0.0191)$ & $(0.0173)$ & $(0.0155)$ \\
\hline \multirow[t]{2}{*}{ Left/right position } & 0.0874 & 0.0137 & 0.0845 & 0.105 & 0.156 \\
\hline & $(0.0657)$ & $(0.0328)$ & $(0.0618)$ & $(0.0733)$ & $(0.0767)$ \\
\hline \multirow[t]{2}{*}{ Women } & $-0.280 * *$ & -0.122 & $-0.218 * *$ & -0.132 & $-0.0892 *$ \\
\hline & $(0.0766)$ & $(0.0797)$ & $(0.0592)$ & $(0.0757)$ & $(0.0350)$ \\
\hline \multirow[t]{2}{*}{ Trust in others } & $0.125 * * *$ & $0.153 * * *$ & $0.123 * * *$ & $0.145^{* * *}$ & $0.114 * * *$ \\
\hline & $(0.0233)$ & $(0.00660)$ & $(0.0110)$ & $(0.0177)$ & $(0.0172)$ \\
\hline \multirow[t]{2}{*}{ Religiousness } & $0.0726^{* * *}$ & $0.0522 * * *$ & $0.0545 * * *$ & $0.0616^{* * *}$ & $0.0343^{*}$ \\
\hline & $(0.0177)$ & $(0.0104)$ & $(0.0112)$ & $(0.0125)$ & $(0.0123)$ \\
\hline \multirow[t]{2}{*}{ Discriminated } & $-0.544 * *$ & $-0.532 * *$ & $-0.438^{* *}$ & $-0.383^{* * *}$ & -0.189 \\
\hline & $(0.153)$ & $(0.183)$ & $(0.135)$ & $(0.0712)$ & $(0.0899)$ \\
\hline \multirow[t]{2}{*}{ Health } & 0.0399 & -0.00637 & -0.00795 & 0.0309 & 0.0621 \\
\hline & $(0.0504)$ & $(0.0361)$ & $(0.0754)$ & $(0.0203)$ & $(0.0373)$ \\
\hline \multirow[t]{2}{*}{ Income } & -0.00679 & -0.0235 & $-0.0393 *$ & -0.00358 & 0.00673 \\
\hline & $(0.0130)$ & $(0.0130)$ & $(0.0149)$ & $(0.0181)$ & $(0.00935)$ \\
\hline \multirow[t]{2}{*}{ Unemployed } & -0.0791 & $-0.175^{*}$ & -0.0440 & -0.105 & 0.0243 \\
\hline & $(0.0895)$ & $(0.0816)$ & $(0.190)$ & $(0.0677)$ & $(0.0544)$ \\
\hline \multirow[t]{2}{*}{ Constant } & $1.291 * * *$ & $1.990 * * *$ & $1.604 * * *$ & $0.713 *$ & 0.606 \\
\hline & $(0.304)$ & $(0.237)$ & $(0.353)$ & $(0.270)$ & $(0.527)$ \\
\hline Observations & 10541 & 14465 & 12067 & 14648 & 12837 \\
\hline Adjusted R square & 0.272 & 0.263 & 0.253 & 0.300 & 0.327 \\
\hline
\end{tabular}

Entries are regression coefficients of OLS regressions absorbing country-case effects. with robust standard errors clustered for country-cases, separetely run for ESS rounds 1-5. Dependent variable: satisfaction with the government. Population and design weights applied.

$* * * \mathrm{p}<0.001 * * \mathrm{p}<0.01 * \mathrm{p}<0.05$ 
Table 7

The effect of the interaction of voter status and education on satisfaction with the government in the first five ESS data rounds (2002, 2004, 2006, 2008, 2010).

\begin{tabular}{|c|c|c|c|c|c|}
\hline & \multicolumn{5}{|c|}{ Education } \\
\hline & Round 1 & Round 2 & Round 3 & Round 4 & Round 5 \\
\hline \multirow[t]{2}{*}{ Government voter } & $1.465^{* * *}$ & $1.141 * * *$ & $1.234 * * *$ & $1.234 * * *$ & $1.346^{* * *}$ \\
\hline & $(0.249)$ & $(0.271)$ & $(0.269)$ & $(0.186)$ & $(0.311)$ \\
\hline \multirow[t]{2}{*}{ Government voter*Education } & 0.00756 & 0.00439 & -0.000231 & 0.00787 & 0.00725 \\
\hline & $(0.0213)$ & $(0.0139)$ & $(0.0218)$ & $(0.0194)$ & $(0.00998)$ \\
\hline \multirow[t]{2}{*}{ Interest } & 0.0660 & -0.0270 & 0.0110 & 0.0785 & 0.0385 \\
\hline & $(0.0425)$ & $(0.0571)$ & $(0.0867)$ & $(0.0646)$ & $(0.0538)$ \\
\hline \multirow[t]{2}{*}{ Education } & -0.0001 & 0.00259 & 0.00319 & 0.00732 & -0.0151 \\
\hline & $(0.011)$ & $(0.008)$ & $(0.012)$ & $(0.018)$ & $(0.011)$ \\
\hline \multirow[t]{2}{*}{ Newspaper reading } & -0.0129 & 0.0579 & 0.0193 & 0.0298 & 0.0260 \\
\hline & $(0.0269)$ & $(0.0470)$ & $(0.0777)$ & $(0.0439)$ & $(0.0456)$ \\
\hline \multirow[t]{2}{*}{ Life satisfaction } & $0.164 * * *$ & $0.180 * * *$ & $0.179 * * *$ & $0.201 * * *$ & $0.196 * * *$ \\
\hline & $(0.0217)$ & $(0.0153)$ & $(0.0191)$ & $(0.0178)$ & $(0.0157)$ \\
\hline \multirow[t]{2}{*}{ Left/right position } & 0.0873 & 0.0121 & 0.0869 & 0.110 & $0.165^{*}$ \\
\hline & $(0.0665)$ & $(0.0331)$ & $(0.0622)$ & $(0.0751)$ & $(0.0766)$ \\
\hline \multirow[t]{2}{*}{ Women } & $-0.289 * *$ & -0.123 & $-0.224 * *$ & -0.130 & $-0.0863 *$ \\
\hline & $(0.0735)$ & $(0.0840)$ & $(0.0582)$ & $(0.0705)$ & $(0.0345)$ \\
\hline \multirow[t]{2}{*}{ Trust in others } & $0.124 * * *$ & $0.152 * * *$ & $0.124 * * *$ & $0.146 * * *$ & $0.114 * * *$ \\
\hline & $(0.0250)$ & $(0.00642)$ & $(0.011)$ & $(0.0183)$ & $(0.0172)$ \\
\hline \multirow[t]{2}{*}{ Religiousness } & $0.073 * *$ & $0.052 * * *$ & $0.055 * * *$ & $0.063 * * *$ & $0.035 *$ \\
\hline & $(0.0183)$ & $(0.0108)$ & $(0.0111)$ & $(0.0131)$ & $(0.0123)$ \\
\hline \multirow[t]{2}{*}{ Discriminated } & $-0.564 * *$ & $-0.523 * *$ & $-0.445^{* *}$ & $-0.409 * * *$ & -0.186 \\
\hline & $(0.160)$ & $(0.177)$ & $(0.138)$ & $(0.0642)$ & $(0.0909)$ \\
\hline \multirow[t]{2}{*}{ Health } & 0.0419 & -0.003 & -0.006 & 0.0343 & 0.0630 \\
\hline & $(0.0493)$ & $(0.0359)$ & $(0.0740)$ & $(0.0197)$ & $(0.0383)$ \\
\hline \multirow[t]{2}{*}{ Income } & -0.00481 & -0.0223 & $-0.0397^{*}$ & -0.0041 & 0.0071 \\
\hline & $(0.0128)$ & $(0.0125)$ & $(0.0155)$ & $(0.0176)$ & $(0.0108)$ \\
\hline \multirow[t]{2}{*}{ Unemployed } & -0.0674 & -0.175 & -0.0446 & -0.119 & 0.0228 \\
\hline & $(0.106)$ & $(0.0879)$ & $(0.190)$ & $(0.0742)$ & $(0.0530)$ \\
\hline \multirow[t]{2}{*}{ Constant } & $0.804 *$ & $1.542 * * *$ & $1.309 * * *$ & 0.110 & 0.165 \\
\hline & $(0.309)$ & $(0.281)$ & $(0.242)$ & $(0.308)$ & $(0.483)$ \\
\hline Observations & 10541 & 14465 & 12067 & 14648 & 12837 \\
\hline Adjusted R square & 0.267 & 0.258 & 0.252 & 0.294 & 0.323 \\
\hline
\end{tabular}

Entries are regression coefficients of OLS regressions absorbing country-case effects. with robust standard errors clustered for country-cases, separetely run for ESS rounds 1-5. Dependent variable: satisfaction with the government. Population and design weights applied.

$* * * \mathrm{p}<0.001 * * \mathrm{p}<0.01 * \mathrm{p}<0.05$ 
${ }^{\mathrm{i}}$ It is worth to note that those with low interest and low knowledge do not remember political information at all.

ii While it might seem plausible to use the left/right ideological position of parties to define the boundaries between competing political camps, we think that comparing the evaluations of government and opposition voters is a better decision on at least two grounds. Firstly, similarly to the Democrat-Republican divide, the government/opposition categories fundamentally reflect "who are with whom" on the political scene of the given country. Thus, they better reflect the boundaries of the competing camps than the left/right categories, especially if a government has a two-sided opposition. Even if opposition parties are ideologically very far from each other, the evaluations of their voters about the performance of the government might be very similar. Secondly, using the government/opposition categories the position of any party in any time period (excluding the period between elections and the investiture of the new government) is unquestionable. Thus, this method is clear and straightforward, which is not unconditionally true for the left/right divide.

iii The exact wording of the question was „Now thinking about the [country] government, how satisfied are you with the way it is doing its job?"

${ }^{\text {iv }}$ We performed the analysis with STATA13, the code we used was $\operatorname{areg}$ y x1 x2 ... [pweight=newweight], absorb(country-case) cluster(country-case) 